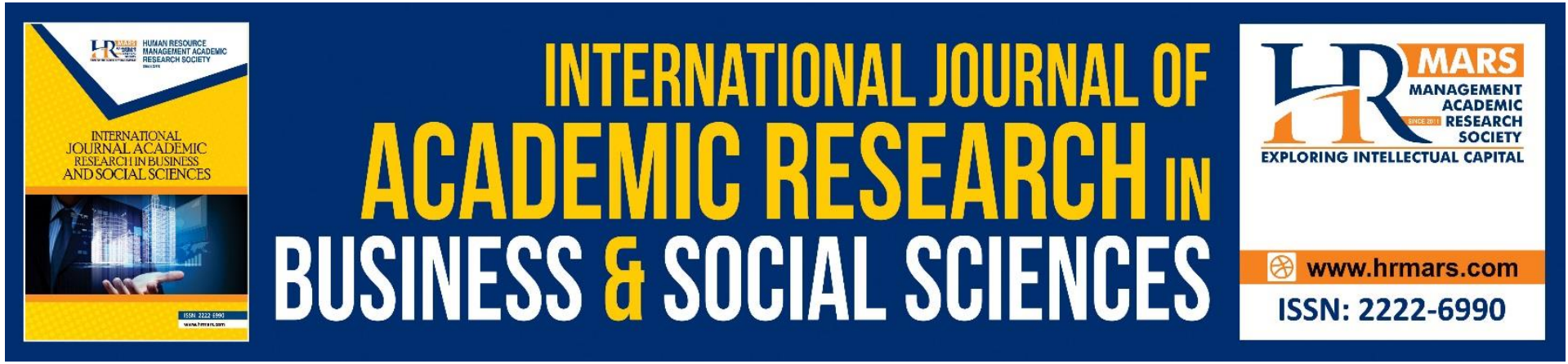

\title{
Deradicalization Program Through Multicultural Education in Higher Education in Indonesia and Malaysia
}

Fathur Rokhman, Norzaidi Mohd Daud, Ali Masyhar, Ahmad Syaifudin, Lulu April Farida

To Link this Article: http://dx.doi.org/10.6007/IJARBSS/v11-i9/11029

DOI:10.6007/IJARBSS/v11-i9/11029

Received: 04 July 2021, Revised: 30 July 2021, Accepted: 20 August 2021

Published Online: 14 September 2021

In-Text Citation: (Rokhman et al., 2021)

To Cite this Article: Rokhman, F., Daud, N. M., Masyhar, A., Syaifudin, A., \& Farida, L. A. (2021). Deradicalization Program Through Multicultural Education in Higher Education in Indonesia and Malaysia. International Journal of Academic Research in Business and Social Sciences, 11(9), 458-468.

Copyright: @ 2021 The Author(s)

Published by Human Resource Management Academic Research Society (www.hrmars.com)

This article is published under the Creative Commons Attribution (CC BY 4.0) license. Anyone may reproduce, distribute, translate and create derivative works of this article (for both commercial and non-commercial purposes), subject to full attribution to the original publication and authors. The full terms of this license may be seen

at: http://creativecommons.org/licences/by/4.0/legalcode

Vol. 11, No. 9, 2021, Pg. 458 - 468

Full Terms \& Conditions of access and use can be found at http://hrmars.com/index.php/pages/detail/publication-ethics 


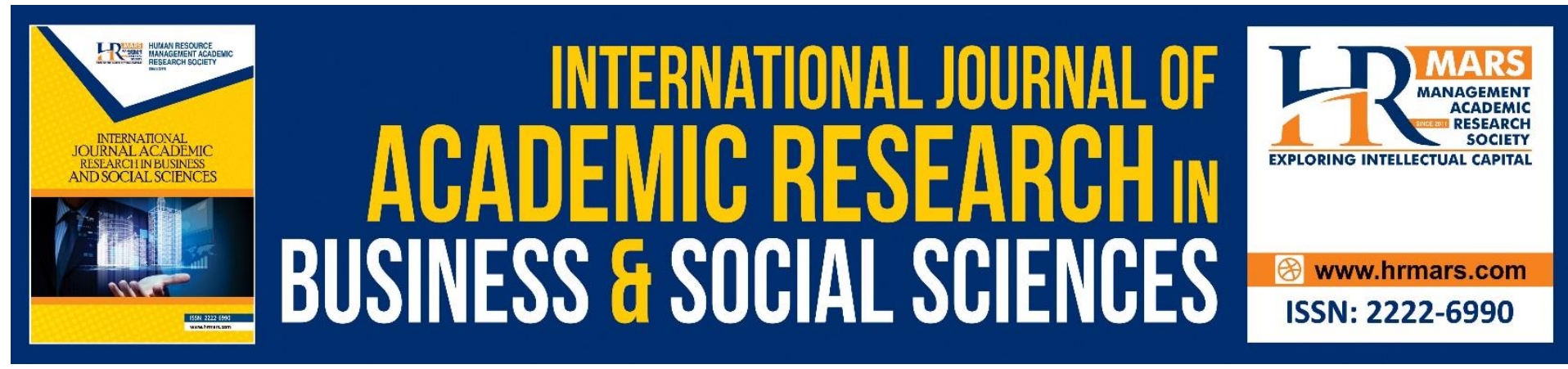

\title{
Deradicalization Program Through Multicultural Education in Higher Education in Indonesia and Malaysia
}

\author{
Fathur Rokhman ${ }^{1}$, Norzaidi Mohd Daud², Ali Masyhar ${ }^{1}$, Ahmad \\ Syaifudin ${ }^{1}$, Lulu April Farida ${ }^{1}$ \\ ${ }^{1}$ Universitas Negeri Semarang, Indonesia, ${ }^{1}$ Universiti Teknologi MARA, Shah Alam, 40450 \\ Selangor DE \\ Email: lulu.farida@mail.unnes.ac.id
}

\begin{abstract}
This study aimed to investigate the pattern and forms of deradicalization in higher education both in Indonesia and Malaysia. It also tried to search for the strategy of deradicalization in higher education levels. This study used qualitative study with ethnography strategy. The research steps consist of grand tour, formulation of preliminary findings and determination of research strategy, exploration of research focus or mini tour, analysis of advanced data, data validity check, final data analysis and formulation of research results, making the report, and post field step. The data collection techniques used in this research were interview, observation, documentation analysis, and focus group discussion. Meanwhile, the data analysis technique used in this research was technique from Miles and Huberman (1994). There were three steps of main activities, they are data reduction, data presentation, and conclusion (Miles \& Huberman, 1994). Result of this study showed that the forms of radicalism in higher education are radicalism in thinking and acting that aimed to terrorism. This form of radicalism is spread through direct and indirect patterns. The former is carried out through religious lectures, student associations, organizations, and dormitories. Meanwhile, the latest one is profiling in the media social and members recruitment. Thus, the deradicalization strategy through multicultural education in institutions is carried out both in a soft and hard approach. The soft approach is carried out to embrace parties who are indicated to understand radicalism, while the hard approach is carried out for parties who have led to illegal acts (terrorism). The multicultural education in Indonesia was created through the foundation of multicultural consciousness in the past. The implementation of multiculturalism as common platform in designing the learning based on Bhinneka Tunggal Ika or unity in diversity is realized through the civics education which is supported by the religion education. Meanwhile the implementation of multicultural education in Malaysia used soft and hard approaches by using religion. This approach is considered to be proper approach particularly when it was given to the Islam majority. By using this approach, the institutions and the lecturer could attempt to grow the Islamic values to develop the respect among fellows even though they have different tribes and religions.
\end{abstract}

Keywords: Deradicalization, Multicultural Education, Higher Education 


\section{Introduction}

Indonesia and Malaysia are two countries which come from the same family. However, as the different history collective experience in the colonial era, both of the countries show the different characteristics. Malaysia owns the geographical area in the form of a peninsula, while Indonesia is an archipelago. Hence, both Indonesia and Malaysia have multicultural mosaics in the form of ethnicities, culture, languages, and religions. Moreover, the majority population in Indonesia and Malaysia are moeslems and still in the progress of being a democratic country (Blij \& Muller, 2004, p. 488).

The diverse multicultural treasure is the nation's valuable potency. On the other hand, unmanaged diversity can cause various problems such as economic, social, and political imbalance. Also the inability of the community to grasp the concept of the diversity which can lead to the decision among the group. Alexandra (2017) stated that aside from the threat of violence, the diversity in Indonesia is extremely susceptible to radicalism (Alexandra, 2017).

Dahana (2010) explained in her study that radicalism will not exist in an empty room. There are some contexts at least which generate the radicalism phenomena. The unfair economical condition, the uncertain social conditions, the law condition which is full of deviations, the dirty politics which shadows the corruption illness, and the civics education installation that is weak cause the susceptible condition of the community to be influenced by the radicalism ideologies. These conditions have led the community in part to search for instant solutions with the simplistic approaches to extricate themselves from the problems. However, in religious radicalism, the fundamentals of theology doctrines are used repeatedly to legitimize the radical attitude and actions (Darraz, 2013, p. 155) even if the radicalism can cause the nation's disintegration (Sundawa, 2017). Therefore, radicalism still becomes a serious problem for many circles (Sahri, 2016).

The radical movements have influenced and even controlled some education institutions such as senior high schools and higher education. Through this radical movement, an indication of being the centre of intolerance, exclusivity, anti-diversity, even violence instillation. In some cases, particularly the public schools, they seem encouraging and even facilitate the radicalism and extremism which tend to behave intolerantly against the difference, discriminatory, anti-democracy, and anti-human rights (Darraz, 2013).

In line with that idea, Husein (2017) also justified that radicalism burst and infiltrated the educated circles and higher education students in various universities. This deviates from the education role which is used as the tool to unify the nation, equalize the opportunities, and develop the self-potency maximally (Husein, 2017). Therefore, by using education, it is expected that all differences or diversity can be minimized, that all citizens get the same opportunity whether it is rich or poor people, men or women, can develop their potency optimally.

The recent research which has been conducted by the research institution in Indonesia recently showed that the trend which is still ongoing, is precisely that the radicalism movement is still continuously spread through the educational institutions which are commonly public educational institutions (Fanani, 2013; Gaus, 2013). On one hand, currently every single second, cyberspace, especially social media, is full of uproar of the hoax news which unsettle the community. Even the news sometimes can lead to the conflict related to the tribes, religions, races and among groups which will result in separatism and radicalism. The data from the Ministry of Communication and Informatics revealed that there were 800.000 Indonesian sites which were indicated as the hoax and hate speech spreaders. The 
fact confirms that the social media has the potency to spread the radicalism virus even separatism over the Unitary State of the Republic of Indonesia (Sunarto, 2017).

The radicalism issue in Malaysia seems relatively less visible in the surface. However, in Sarawak Malaysia has become the headquarter of the Daulah Islam Nusantara (DIN) which has determined to unify Sarawak, Sabah, South Phillipine, Borneo, and Sulawesi. Moreover, the number of Malaysia residents who have been recruited by ISIS is about 40 people and in Phillipine is about 200 (Hashim, 2015). There is also a fact stated that Malaysia becomes the exporter of radicalist figures. The action of Noordin Mohd Top and Azahari Husin in Indonesia is a valid proof of Malaysian influence towards radicalism in Southeast Asian.

Based on those reasons, a strategy to prevent the radicalism is necessary. Jazuli (2016) stated that The precaution strategy can be conducted through two strategies which are hard approach and soft approach. The strategies were conducted by integrating the prevention and enforcement also conducting the proactive law enforcement approach without overriding the rule of law and legality principle. With this approach, the radicalism prevention can be done without waiting the occurence of the radical action and its effect. So, this perspective position the law enforcement towards the various laws and regulations which have been made as a strategy to prevent the radicalism. Hence, a more structured, polite, and full of Eastern-culture deradicalization is needed. It is the internalisation of multiculturalism values through the multicultural education. The philosophical foundation of multicultural education is accomodating the gap of education, culture, and religion. Those three things have interrelated orientation which boil down to humanity. This is in line with one of multicultural education orientation which is humanity (Rokhmad, 2012; Suprapto, 2014; Andaryuni, 2014).

Based on those explanations, the purpose of this study is to identify the form and pattern of radicalism in higher education and arrange the deradicalization strategy through multicultural education in higher education. It was done both in Indonesia which was in Universitas Negeri Semarang and in Malaysia which was in Universiti Teknologi Mara. These were the research questions in this study:

1) What are the forms and patterns of radicalism in higher education?

2) How are the deradicalization strategies through multicultural education implemented in higher education?

\section{Literature Review Multicultural Education}

Multicultural education surface as the solution of citizens' dissatisfaction towards the education system which has been run by the authorities (Andaryuni, 2014). The terms of multicultural education can be used both in the descriptive or normative level which describes the issues related to the multicultural community. It can have broader definition which includes the definition of the consideration towards the education policies and strategies in the multicultural community. In the descriptive context, multicultural education should contain the themes of tolerance, etnocultural and religion differences, the danger of discriminations, conflict settlement and mediation, human rights, plurality, universal humanity, and other relevant subjects (Tilaar, 2002, p. 15).

The global commitment as recommended by UNESCO on October 1994 in Geneva resulted four recommendation about the concept of multicultural education, they are: (1) education should develop the ability to acknowledge and accept the values which exist in the personal diversity, sex, commnity and culture also develop the ability to communicate, share, 
and collaborate with others; (2) education should strengthen the self-identity and encourage the convergence of ideas and settlements which strengthen the brotherly peace and solidarity between an individual and community; (3) education should improve the peace development on the students, so they are able to build the quality of tolerance, patience, willingness to share and maintain it strongly (Andaryuni, 2014).

Multicultural education is based on the assumption that every single individual has the different identity, history, environment, and life experiences. The difference is the most important and authentic identity of every human being from its similarity. The teaching and learning activity is not aimed for the students to master as much as knowledge, but how every student can experience their own learning process and live in the classroom and educational environment. In this case, a teacher or educator is not placed as the most important single actor in the learning process who knows everything and is talented (Andaryuni, 2014). Nevertheless, an efficient and productive educator can create a situation in which students can learn in unique ways. Class is created not to bury the personal identity, but to enlarge the opportunities of every student to actualize themselves.

\section{Radicalism and Deradicalism}

Radicalism comes from Latin language, radix, which means root. The essence of radicalism is the soul attitude on carrying changes. The demands of change from a group of people who follow this concept is a significant change that is really different from the current system. In achieving goals, they often use violence (Ahab, 2015; Khamid, 2016). Radicalism is often linked with terrorism as they will do anything to assasinate their enemies. Radicalism is often linked with the extreme groups in certain religions.

The radicalism tends to terrorism actions which can be interpreted as a violent action which is not approved by the government. This action is carried out by a person or a group of people who wants to get power and influence in society (Dafrizal \& Ibrahim, 2010, p. 36). The biased perspective on the radicalism stigma, a group will accuse other groups as radical groups, there is no clear standard on judging when a person or a certain group is called a radicalist. For the current time, the appraisal authority is given to the mass media perception or the influence of politics power. Those things can be proven by reading the radicalism history from time to time (Mage, 2017, p. 238).

The radicalism objective is to make a change until the root or source and to realize this effort, they will alway use violence as their methods and oppose the current society's structure. They will always have careful programs, and have the philosophical basis to justify the dissatisfaction and introduce the innovation. Radicalism is related to the revolution. They always have long term plans such as causing dramatic changes in government like revolution, civil war, or war among countries. Replacing a country's ideology with their ideology, influencing the policy maker whether it is in the local, national, regional, or international and getting the political recognition as a legal entity to represent a tribe or national group.

Deradicalization is all efforts to transform from the belief or radical ideology to unradical with multi approaches and interdisciplinaries (religion, social, culture, and others) for affected people by the radicalism. Based on that, deradicalization tends to be an effort to conduct cognitive changes or moderate someone's thought or belief. Therefore, deradicalization has long term plans. It works in the ideology level based on its aim to change the doctrine and interpretation of terrorism religious understanding (Barret \& Bokhari, 2009; Boucek, 2008; Abuza, 2009). 
As an activity program, the implementation of deradicalization can be in a form of identification, rehabilitation, re-education, and resocialization for affected individuals or groups by prioritizing the empowerment principle, human rights, law supremacy and equality.

The main objective of deradicalization is to make the terrorist or the group who do violence to feel disposed to leave or release themselves from the terrorism actions. Particularly, the objectives of deradicalization are

1) Making the terrorists to leave the terrorism and violence actions.

2) Radical groups support moderate and tolerant thought.

3) Radicalists and terrorists can support the national programs in building the state and national life.

\section{Methodology}

This research used a qualitative method with ethnography strategy. Creswell (2012: 462) elaborated "Ethnographic design are qualitative research procedures for describing, analyzing and interpreting a culture-sharing group's patterns of behavior, beliefs, and language that develop over time." This ethnography choice is based on the type of qualitative research which has a focus to describe, analyze, and interpret the group culture. Related to the education, as it is explained by Wiersma and Jurs (2009), ethnography is "The process of providing holistic and scientific descriptions of educational system, processes, and phenomenon within their specific contexts." (p. 273). Hence, education is the most proper method to explore multicultural education which is formulated in the research problems focus.

This ethnographic research is conducted following the steps and process of qualitative research which is inductive. The research steps consist of grand tour, formulation of preliminary findings and determination of research strategy, exploration of research focus or mini tour, analysis of advanced data, data validity check, final data analysis and formulation of research results, making the report, and post field step.

The data collection techniques used in this research were interview, observation, documentation analysis, and focus group discussion. Meanwhile, the data analysis technique used in this research was technique from Miles and Huberman (1994). There were three steps of main activities, they ere dta reduction, data presentation, and conclusion (Miles \& Huberman, 1994). Data reduction was the process of selecting, recollection, simplification, abstraction, and transformation of "raw" data which appeared in the data source. Next activity was presenting the data which was arranged systematically. The data presented was in the matrix and table to ease the researcher to see and understand the data. The drawing conclusion was conducted to formulate the forms and patterns of multicultural education. The conclusion still needed to be re-examined. This examination was conducted to check the different data sources and discussion through FGD. The scheme of the analysis technique could be depicted as figure 1 : 


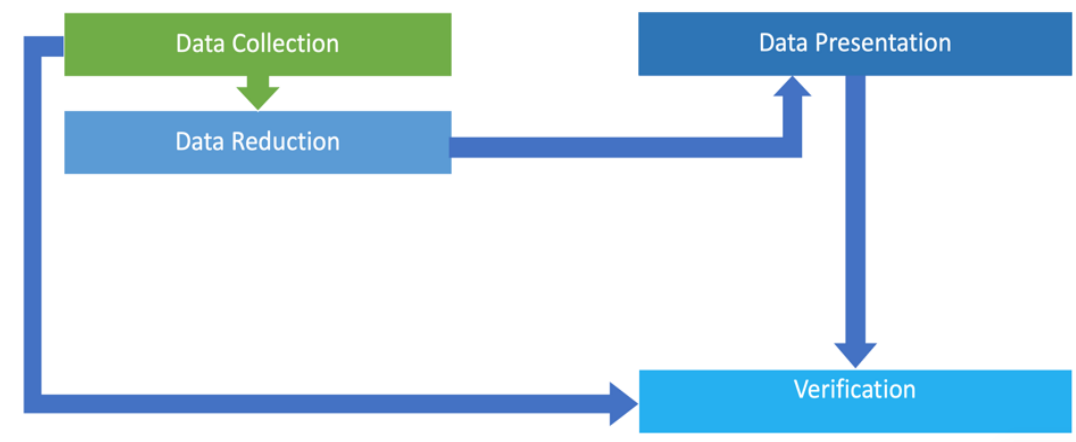

Figure 1 analysis technique

\section{Results and Discussion}

\section{Forms and Patterns of Radicalization in Higher Education}

Indonesia and Malaysia have diverse resources both human resources and natural resources. Both of the countries also have similarities and a lot of differences. Those differences often cause different perspectives and end up with conflicts. In Indonesia, the differences such as social, economic, and cultural differences often cause conflicts for its citizens. The big gap and inequality which have occured makes some people attempt to release themselves from their unfavorable situations such as poverty, unequal law enforcement, and social gap.

Meanwhile in Malaysia, the radicalization is spread through certain platforms such as students association and communities. As Malaysia also has moeslems as majority and most of them are devout moeslems, the radical people attempt to use their strategy through religion to influence the people. Moreover, higher education is the time when the students start to live by themselves and have a lot of choices to do. It is such a momentum for these radical groups to spread the doctrines and hatred as drawn in the figure 2 which is spread out both direct and indirect.

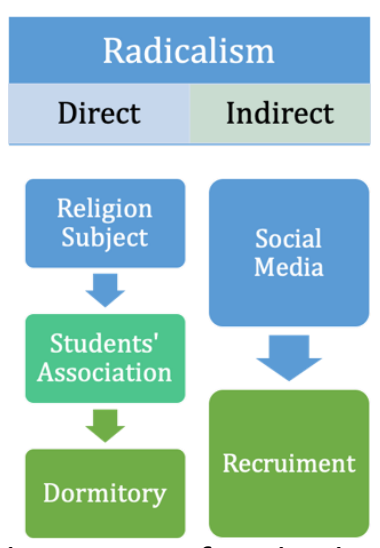

Figure 2 Forms and Patterns of Radicalization in Higher Education

Some people who have radical thoughts would be determined to change the situation as they will. These radicals will provide the people with unfavorable conditions with everything they want and use them to reach the radical goals directly in the religion subject in the university, through students' association, and discussion in the dormitory. Meanwhile, the form and patterns of radicalization indirectly occurred such as in certain social media circles and recruitment of association, through certain doctrines, and the spread of hoaxes 
through social media. Being educated is not a guarantee for them not to join these radical groups as these radical groups always have innovation and certain ways to influence people with their justifications.

\section{Strategy of Deradicalizaton through Multicultural Education in Indonesia and Malaysia}

The social conflicts in Indonesia or in other parts of the world have been caused by the different cultures. The different culture often causes social prejudice which develops to be physical conflict such as fighting, brawling, even war. It does not happen because of the different culture as the reality tends to conflict, but because of the different culture that is interpreted less precisely. The wrong interpretation makes instead of being the cultural excellence, it becomes the reality at hand. Under the unique and specific context, the social conflicts which were because of the different cultural background have happened in various countries. Indonesia, a country with cultural diversity, also experiences social conflicts many times because of the different culture. The conflicts in Poso, Ambon, Sampit, Cikeusik, and Madura were caused by different cultures. The inability to accept another person or group as the same humans caused group prejudice which easily developed as violence.

The massacre of Ahmadiyah followers in Cikeusik on 6th February 2011 happened because the perpetrators regarded the victims as bad social entities. The perpetrators regarded the Ahmadiyah congregation as a misguided group and even infidel. When the collective assumption was capitalized into hatred, it was really easy to make different sects into a social conflict. The influenced mass could not hold their anger as they often experienced the crowd of psychological traps.

The social conflicts in Indonesia often occur because of the different cultures which could be dozens, hundreds, or even thousands. There were big conflicts with major damage that were noted by the mass media, remembered by the public, and became collective lessons. But there were also small conflicts that occured as they were small and made it less attention.

There were small conflicts based on different culture which were easy to be found around us for example in the internal Islam congregation, there was a tense among the hardliners, moderate, and liberal followers. Some of the tenses developed as violent actions, but the other was still hidden anger. Eventhough the hidden anger was not dangerous but it was easier to grow as a terrible social conflict.

Based on those conditions, the community should reflect themselves deeper to contemplate the meaning of different cultures and attempt to make wise decisions based on knowledge not social prejudice. The deradicalization strategy through multicultural education in higher education in Indonesia was by providing the civics subject which was supported by religion education. Moreover, multicultural education was done comprehensively through the implementation of the curriculum whether it was written curriculum, implicit curriculum, integrative evaluation and the lecturers who had productive understanding, attitude and actions in giving the multicultural education for their students.

Meanwhile, as a neighboring country, Malaysia has the same social culture as Indonesia. But on the other hand, they have different political systems which make various differences. They were different historically and also their cultural diversity. According to Maaruf \& Abdul Rahman (2018), Malaysia as a country has always been the point of various cultures and this is very much reflected to the overall population census, which classifies the nation to be made up of these various races; Malay, Chinese, Indian, Orang Asli, Kadazan, Ibanese, etc. Generally, the tribes in Malaysia are divided into three groups. Anak Melayu 
tribe is a term for the indigeneous people in Malaysia Peninsula which is categorized as Melayu people. They live in Johor, Kedah, Kelantan, Melaka, Pahang, Perak and Terengganu. The second group is Melayu Anak Dagang, a term for the tribes who come from Indonesian archipelago and Thailand but they have been categorized as Melayu Malaysia. They are Aceh, Banjar, Minang, Javanese, Mandailing, Bugis, Kampar, Kerinci and Pattani. The third group is Melayu Kacukan, a term for the people who were born from mixed marriages between Melayu Malaysia and other tribes. This group includes Arabian Melayu, Chinese Melayu, Europe Melayu, Indian Melayu, and Turkish Melayu.

The researchers in Malaysia have agreed that multicultural education is an absolute necessity that must be fulfilled so that Malaysia as a country can survive. According to Salleh (2014) and Yusof (2015), the aim of multicultural education is not only to teach students about groups and other countries. This education is also to help the students to be used to the idea that there are so many life styles, languages, culture, and perspectives. The aim of multicultural education is to attach positive feelings to the multicultural experience so every single student will feel inclusive, respected, and also feel kindness and respect to other ethnicities and cultures.

To implement multicultural education, Malaysia has used various approaches. Omar (2014) exemplified one of the approaches used was religious approach. This approach was considered as the right approach as it was implemented to the community which had muslims as majority. By this approach, schools and lecturers attempted to use the Islamic values to develop mutual respect among the society even though they have different tribes and religions.

Tolerance is a statement from the holy Quran which stated the cultural diversity as sunnatullah or God's law. It means that the different races, tribes, and culture is based on God's will, the All-Wiser. As it is God's will, so humans have the obligation to follow it. In this doctrine, there is an advice for humans to respect the cultural diversity as the diversity is God's will. The existence of Melayu, Chinese, Indian, and other tribes in Malaysia is the God's will. This approach is a plausible approach as the majority of Malaysian is devout moeslems.

This research constructed a Soft Approach and Hard approach are the strategy of Deradicalization through multicultural education in Indonesia and Malaysia. The soft approach is carried out to embrace parties who are indicated to understand radicalism, while the hard approach is carried out for parties who have led to illegal acts (terrorism). Multicultural education give the rational foundation for the students, the education is integrated with various educational institutions and the practices in community. The multicultural education both Indonesia and Malaysia were created through the foundation of multicultural consciousness since the past.

\section{Conclusion}

The multicultural education in Indonesia was created through the foundation of multicultural consciousness in the past. That foundation is devoted through the country's national principle, Pancasila and the 1945 constitution. The implementation of soft approach multiculturalism as a common platform in designing the learning based on Bhinneka Tunggal Ika or unity in diversity is realized through the civics education which is supported by the religion education. The multicultural education in higher education will be comprehensive in the form of respecting the various races and religions. This hard approach is supported through the written curriculum and implicit curriculum, productive attitude and actions in providing the multicultural education for the students, 
Meanwhile the implementation of multicultural education in Malaysia used various approaches. One of the approaches was the religion approach which covers both soft and hard approaches. This approach is considered to be proper approach particularly when it was given to the Islam majority. By using this approach, the institutions and the lecturer could attempt to grow the Islamic values to develop the respect among fellows even though they have different tribes and religions. As an essential value which is believed by its followers, Islam has owned the learning that obliges its followes to respect each others.

\section{References}

Abdul Rahman, S. B., Maaruf, S. Z. (2018). Pre-service art teachers' perception of multicultural art education and teaching students from multicultural background: An exploratory study. Asian Journal of University Education (AJUE), 14(1), 89-102.

Ahab. (2015). Radikalisme :Pengertian, Sejarah, Ciri, Kelebihan dan Kekurangan. IImu Dasar.

Alexandra, F. (2017). "Analisis Kajian Terorisme dan Radikalisme dalam 3 Perspektif Teoritis". Jurnal Paradigma, 6(3), $137-146$.

Andrayuni, L. (2014). "Pendidikan Multikultural di Perguruan Tinggi (Studi Terhadap STAIN Samarinda)." Fenomena, 6(1), 55-64.

Borg, W. R., \& Gall, M. D. (1983). Education Research: An Introduction. (4 ${ }^{\text {th }}$ Ed). London: Longman Inc.

Dafrizal \& Ibrahim, F. (2010). "Pembingkaian Metafora dan Isu Terorisme: Satu Interpretasi Konseptual". CoverAge : Journal of Strategic Communication, 1(1), 33 - 45.

Dahana, R. P. (2010). "Kekerasan di Batin Kita." Arus Pemikiran Islam Dan Sosial, 5(2), 29-31.

Darraz, M. A. (2013). Radikalisme dan Lemahnya Peran Pendidikan Kewargaan. Jurnal Maarif: Arus Pemikiran Islam Dan Sosial., 8(1), 154-173.

Fanani, A. F. (2013). "Fenomena Radikalisme di Kalangan Kaum Muda." Maarif: Arus Pemikiran Islam Dan Sosial., 8(1), 4-13.

Gaus, A. F. A. (2013). "Pemetaan Problem Radikalisme di SMU Negeri di 4 Daerah." Maarif: Arus Pemikiran Islam Dan Sosial, 8(1), 174-191.

Husein, M. T. (2017). “Fenomena Radikalisme di Indonesia". Jurnal Rausyan Fikr, 13(2).

Jazuli, A. (2016). "Strategi Pencegahan Radikalisme dalam Rangka Pemberantasan Tindak Pidana Terorisme (Prevention Strategy of Radicalism in Order To Wipe Out The Terrorism Crime)." Jurnal Ilmiah Kebijakan Hukum (JIKH), 10(2), 197-209.

Khamid, N. (2016). "Bahaya Radikalisme terhadap NKRI." Millatī: Journal of Islamic Studies and Humanities, 1(1), 123-152.

Lembaga Studi Sosial dan Agama. (2012). Laporan tahunan kebebasan beragama dan berkeyakinan di Jawa Tengah Tahun 2012. Semarang: Lembaga Studi Sosial dan Agama bekerja sama dengan Yayasan Tifa.

Mage, R. I. (2017). "Prospek Gerakan Radikalisme di Indonesia." Jurnal Populis, 2(3), 237-252.

Rokhmad, A. (2012). "Radikalisme Islam dan Upaya Deradikalisasi Paham Radikal". Walisongo, 20(1), $79-114$.

Sahri. (2016). "Radikalisme Islam di Perguruan Tinggi Perspektif Politik Islam". Al-Daulah: Jurnal Hukum Dan Perundangan Islam, 6 (1), 237 - 268.

Sunarto, A. (2017). DAMPAK MEDIA SOSIAL TERHADAP PAHAM RADIKALISME. Nuansa, 10(2), 126-132. https://doi.org/10.29300/nuansa.v10i2.647 
Suprapto, R. (2014). “Deradikalisasi Agama melalui Pendidikan Multikultural-Inklusiv (Studi pada Pesantren Imam Syuhodo Sukoharjo). PROFETIKA: Jurnal Studi Islam, 15(2), 246 260.

Tilaar, H. A. R. (2002). Perubahan Sosial dan Pendidikan; Pengantar Paedagoik Transformatif untuk Indonesia. Jakarta: Grassindo.

Wiersma, E. W., \& Jurs, S. G. (2009). Research Methods in Education: An Introduction (8th Ed) New Jersey: Pearson Education, Inc.

Miles, M. B., \& Huberman, A. M. (1994). Qualitative Data Analysis:A Source Book of New Methods. Beverly Hills: Sage Publications

Putra, N. (2012). Metode Penelitian Kualitatif Pendidikan. Jakarta: RajaGrafindo Persada.

Saukko, P. (2003). Doing Research in Cultural Studies: An introduction to classical and new methodological approaches. London: Sage Publications.

Creswell, J. W. (2012). Educational research: Planning, conducting, and evaluating quantitative and qualitative research (4th ed.). Boston, MA: Pearson. 